\title{
A Belt and Road Initiative na mídia brasileira
}

\section{The Belt and Road Initiative in the Brazilian media}

\section{La Iniciativa de la Franja y la Ruta en los medios brasileños}

1. Doutor em Sociologia pela Universidade de São Paulo (USP). Pesquisador do Centro Brasileiro de Análise e Planejamento (CEBRAP) e Research Fellow na Social Accountability International. ORCID Id: https://orcid.org/0000-0002 9147-7116. (1D)

2. Mestranda em Economia Internacional pela Peking University Business School. Especialista em Políticas Públicas e Gestão Governamental do Governo de Minas Gerais. ORCID Id: https://orcid. org/0000-0002-5182-4451. (1D)

3. Doutorando em Sociologia pela Universidade de São Paulo (USP). Bolsista do Conselho Nacional de Desenvolvimento Científico e Tecnológico (CNPq). ORCID Id: https://orcid.org/0000-0002 3076-0815. (1D)

\section{lan Prates ${ }^{1}$}

Carolina Santos Lages ${ }^{2}$

Vitor Matheus Oliveira de Menezes ${ }^{3}$

DOI: 10.5752/P.2317-773X.2020v8.n3.p128

Recebido em: 04 de dezembro de 2019

Aceito em: 13 de julho de 2020

\section{Resumo}

Este artigo apresenta uma avaliação da percepção da Belt and Road Initiative (BRI) na mídia brasileira. Essa avaliação é relevante diante do movimento de aproximação entre os países e da especulação da entrada do Brasil na BRI, embora o país tenha mantido uma distância deliberada da iniciativa. Nesse contexto, o sucesso de uma possível adesão ao BRI pelo Brasil - uma democracia pluralista e multipartidária - depende em larga medida do grau de consenso em torno dos temas, seja nas arenas formais de decisão, seja junto à opinião pública. O trabalho analisou 266 artigos/reportagens/colunas de opinião dos principais veículos de comunicação brasileiro entre 2017 e 2019. Concluímos que, atualmente, há um elevado grau de desconhecimento sobre a BRI e que o assunto é tratado de forma ainda bastante superficial pela mídia brasileira. Esse fato configura uma especial oportunidade para iniciativas que busquem moldar a imagem da BRI entre os setores da sociedade brasileira - empresariado, tomadores de decisão, academia, membros do governo, classe política, sociedade civil e opinião pública. Por outro lado, deve-se ter em mente que o grau de polarização social e ideológica no Brasil torna a construção de consensos especialmente desafiadora.

Palavras-chave: Belt and Road Initiative; China; Brasil; mídia.

\section{AbSTRACT}

This paper presents an assessment of the perception of the Belt and Road Initiative (BRI) in the Brazilian media. This assessment is relevant in light of the movement between countries and the speculation concerning Brazil's entry into the BRI, even if the country has kept a deliberate distance from the initiative. In this context, the success of a potential adhesion to the BRI by Brazil - a pluralist and multiparty democracy - largely depends on the degree of consensus on the issues at play. This consensus encompass formal decision-making arenas as well 
as public opinion. We analyzed 266 articles/ news reports/opinion columns in the main Brazilian media vehicles between 2017 and 2019. We arrived at the conclusion that there is currently a high degree of unfamiliarity about the BRI and that the subject is reported in a very superficial way by the media. This presents a special opportunity for initiatives that seek to shape BRI's image among sectors in Brazilian society - business, decision makers, academia, members of government, the political class, civil society, and public opinion. Nevertheless, we should bear in mind that the current elevated social and ideological polarization in Brazil makes consensus building especially challenging.

Keywords: Belt and Road Initiative. China. Brazil. Media.

\section{RESUMEN}

Este paper presenta una evaluación de la percepción de la Iniciativa de la Franja y la Ruta (BRI) en los medios brasileños. Esta evaluación es relevante en vista del movimiento hacia lazos más estrechos entre países y las especulaciones sobre la entrada de Brasil en el BRI, aunque el país ha mantenido una distancia deliberada de la iniciativa. En este contexto, el éxito de una posible adhesión al BRI de Brasil - una democracia pluralista y multipartidista - depende en gran medida del grado de consenso en torno a los temas, ya sea en los foros formales de decisión o con la opinión pública. El trabajo analizó 266 artículos / reportajes / columnas de opinión de los principales medios de comunicación brasileños entre 2017 y 2019. Concluimos que en la actualidad existe un alto grado de desconocimiento sobre el BRI y que el tema todavía es tratado de manera muy superficial por los medios brasileños. Este hecho representa una oportunidad especial para iniciativas que buscan moldear la imagen del BRI entre los sectores de la sociedad brasileña: empresarios, tomadores de decisiones, academia, miembros del gobierno, clase política, sociedad civil y opinión pública. Por otro lado, debe tenerse en cuenta que el grado de polarización social e ideológica en Brasil hace que la construcción de consensos sea especialmente desafiante.

Palabras clave: Belt and Road Initiative. China. Brasil. Medios de comunicación.

Introdução

Devido à sua dimensão geográfica e implicações políticas, a Belt and Road Initiative (BRI) é o principal projeto chinês de cooperação internacional. Ele inaugura uma nova era de globalização e sela de vez o papel da China como uma potência mundial. A época do seu lançamento, por exemplo, foi recorrentemente comparada ao Plano Marshall, devido ao seu potencial impacto econômico e político (SHEN; CHAN, 2018). Com cinco áreas prioritárias de cooperação (coordenação de políticas, conectividade de infraestrutura, facilitação de comércio, cooperação financeira e laços interculturais), os investimentos apresentarão relevantes impactos econômicos e sociais aos países que aderirem à iniciativa.

A incorporação do Brasil à BRI poderia ajudar a superar as dificuldades que o país - e o restante da América Latina, de um modo geral - enfrenta para realizar os investimentos adequados nas áreas de infraestrutura, energia, tecnologia e inovação (ARBACHE, 2019). O Brasil é especialmente interessante para a China, devido à vantagem competitiva das suas empresas, que têm desenvolvido ao longo dos últimos anos um avançado know-how e conhecimento tecnológico nessa área (CENTRO BRASILEIRO DE RELAÇÕES INTERNACIONAIS, 2019). No campo 
4. Todavia, uma longa e polêmica

discussão acerca da segurança da tecnologia oferecida pela China, cujo produto é o melhor custo-benefício do mercado, atrasa a implantação do $5 \mathrm{G}$ no Brasil. Esse é apenas um dos pontos envolvidos na disputa da liderança tecnológica mundial entre os Estados Unidos e China.

5. 0 Debt-Trap Diplomacyé o nome dado à política externa chinesa de intencionalmente conceder crédito excessivo a um país, fragilizando suas finanças, e, então, obter concessões econômicas e políticas do devedor. energético, as oportunidades se abrem a partir da combinação entre a variedade de recursos presentes no território brasileiro e o seu ambiente regulatório. Já a cooperação em Inteligência Artificial, Machine Learning, Internet of Things e internet de alta velocidade - áreas em que a China exerce uma proeminência global - se mostra imprescindível para alavancar o desenvolvimento do país. Nesse contexto, vale reforçar que a disponibilização de internet $5 \mathrm{G}$ no país é especialmente importante para viabilizar a criação e o aprimoramento de negócios ${ }^{4}$.

Há, contudo, alguns receios. Do ponto de vista econômico, a maleabilidade da BRI (seja com respeito aos objetivos esperados, seja com respeito aos mecanismos de cooperação e governança), bem como as possibilidades de endividamento que podem culminar no chamado debt-trap ${ }^{5}$, são os aspectos mais ressaltados (PIRES, 2019; CENTRO BRASILEIRO DE RELAÇÕES INTERNACIONAIS, 2019). No campo diplomático, há o receio de uma possível reação negativa de Washington, no contexto do acirramento da rivalidade entre Estados Unidos e China. E, por fim, no âmbito interno, destacam-se as (in)capacidades do Estado brasileiro em estabelecer arranjos institucionais de longo prazo que permitam ao país superar suas históricas deficiências estruturais (HIRATUKA, 2018).

Entretanto, é importante refletir não apenas sobre como os especialistas têm discutido os potenciais pontos positivos e negativos da BRI, mas também sobre como tem sido moldada a percepção da sociedade brasileira sobre o tema. Este artigo pretende justamente contribuir com esse tema, ao abordar a cobertura da BRI entre alguns dos principais veículos de mídia do Brasil. Ao fazê-lo, pretendemos chamar atenção para a imagem da BRI fora dos meios especializados e acadêmicos. Afinal, seja através da BRI ou de outros mecanismos, as relações entre Brasil e China têm se aprofundado e se estreitado consideravelmente, e seus impactos na sociedade brasileira vão muito além das questões macroeconômicas. Elas simbolizam a conexão do país com o oriente, sendo que o estreitamento dessas relações aproxima uma realidade cultural e política que pode suscitar novas discussões e moldar o comportamento da sociedade brasileira. Essas mudanças potenciais cobrem um espectro amplo, desde hábitos de consumo, como a indústria do skincare, até o questionamento ou releitura de máximas ocidentais de liberdade e democracia. Justamente por isso, uma primeira aproximação da imagem que a sociedade brasileira tem da BRI joga luz sobre um tema que exige o mínimo de consenso entre os decisionmakers do país, desde governo ao empresariado, algo cada vez mais difícil num contexto de crescente polarização social e ideológica.

Além desta introdução, o artigo se divide da seguinte forma. A próxima seção apresenta uma contextualização das relações diplomáticas, comerciais e de investimento entre Brasil e China nas últimas décadas. A seção 2 apresenta uma breve contextualização da BRI e como ela se insere na relação entre Brasil e China. A seção 3 apresenta a metodologia e a seção 4 os principais resultados. Ao final, apresentamos algumas indicações com o intuito de contribuir, no que se refere à RBI, com uma cooperação saudável entre os dois países. 
Diplomacia, comércio e investimento na relação Brasil-China

A relação China-Brasil se fortaleceu ao longo dos últimos vinte anos e, apesar da crise desencadeada pela pandemia do Covid-19 e das questões comerciais entre EUA-China, a expectativa é que ela se intensifique ainda mais. Sua relevância no cenário internacional também é ascendente (ZHIWEI, 2019). Os interesses estratégicos comuns têm impulsionado a relação bilateral nos campos da política, economia, comércio e cultura.

A relação diplomática entre o Brasil e a República Popular da China foi estabelecida em agosto de 1974, após uma mudança na abordagem diplomática brasileira, de "fronteiras ideológicas" pró-EUA para um "pragmatismo responsável” mais amplo. Posteriormente, em 1993, foi estabelecida uma parceria estratégica que reconheceu interesses mútuos entre os países (ZHIWEI, 2019), indicando uma elevação no status diplomático. O Brasil foi o primeiro país a ter esse tipo de relacionamento com a China.

Outro fato relevante foi o estabelecimento da Comissão Sino-Brasileira de Alto Nível de Concertação e Cooperação (COSBAN) para aprofundar a relação bilateral, em maio de 2004. Esse é um dos mecanismos brasileiros de coordenação bilateral mais abrangentes. Nele, foram definidos comitês diversos, como no tocante à política, economia, comércio, ciência, tecnologia, aviação, cultura, agricultura, energia, minerais e educação, com a finalidade de impulsionar a cooperação entre os países (ZHIWEI, 2019). Em 2015, os dois governos elegeram a tecnologia como prioritária no Plano de Ação 2015-2021, e incorporaram no acordo iniciativas de silvicultura, astronomia, meteorologia e prevenção e mitigação de desastres naturais.

A importância da cooperação Brasil-China vai além da relação bilateral per se. Ela inspira e reforça outras cooperações sul-sul, ao integrar dois dos maiores países em desenvolvimento. Tal característica faz deles, junto com a Rússia, os principais representantes dos BRICS, grupo que não apenas amplia a cooperação entre os países em desenvolvimento, mas também têm um papel importante no esforço de construção de uma nova ordem mundial com maior equilíbrio político (CENTRO BRASILEIRO DE RELAÇÕES INTERNACIONAIS, 2019).

Embora os trabalhos do BRICS sejam lentos, o compromisso dos países membros com o fortalecimento e concretização do grupo é permanente. Dois resultados se destacam: o aumento da representatividade dos países em foros decisórios relevantes, como o Fundo Monetário Internacional e Banco Mundial' ${ }^{6}$, e a consolidação do New Development Bank (CENTRO BRASILEIRO DE RELAÇÕES INTERNACIONAIS, 2019).

A relação comercial Brasil-China também sofreu uma transformação considerável. Os números brasileiros de exportação e importação com EUA, região do Euro e China ilustram essa mudança. Por mais de sete décadas, os EUA foram o maior parceiro comercial do Brasil. Essa hegemonia terminou em março de 2009, com a substituição dos EUA pela China (ZHIWEI, 2019). Em 1999, os EUA, a região do Euro e a China eram o destino de $22 \%, 25 \%$ e $1 \%$ das exportações brasileiras, respectivamente. Em 2018, os números respectivos foram de 12\%, 15\% e 26\%. Já em 1999, 24\% das importações brasileiras provinham dos EUA, 26\%
6. A reinvindicação do grupo por maior participação levou a alteração da equação societária das instituições pertencentes ao acordo de Bretton Woods. Com isso, hoje o BRICS possui " $16,52 \%$ dos votos nos foros decisórios do FMl (contra $14,28 \%$ dos EUA) e $13,08 \%$ nos do Banco Mundial (contra 15,68\% dos Estados Unidos)" (CENTRO BRASILEIRO DE RELAÇÕES INTERNACIONAIS, 2019, p. 56). 
da região do Euro e $2 \%$ da China. Vinte anos depois, essa distribuição se reequilibrou, e os números respectivos foram de 16\%, 16\% e 19\%. Assim, chama atenção que a parceria comercial brasileira se deslocou dos norte-americanos e europeus para os chineses (CYSNE, 2019).

No entanto, se por um lado a China contribuiu para um maior equilíbrio comercial entre os parceiros brasileiros, a relevância comercial do Brasil para a China é pequena: em 2019, apenas 3,6\% dos produtos importados pela China eram brasileiros. Além disso, as exportações chinesas para o Brasil correspondem a 1,3\% do total exportado. Vale ressaltar que, em 1999, esses números eram de $0,4 \%$ e $0,6 \%$. Outro ponto relevante é o tamanho da economia de ambos os países. O Produto Interno Bruto (PIB) brasileiro é inferior a um sétimo do PIB chinês, o que certamente influencia o poder de negociação na relação comercial (CYSNE, 2019). Os gráficos abaixo resumem esses números:

Gráficos 1 e 2 - Importação e exportação - Brasil e China, 1999 - 2018

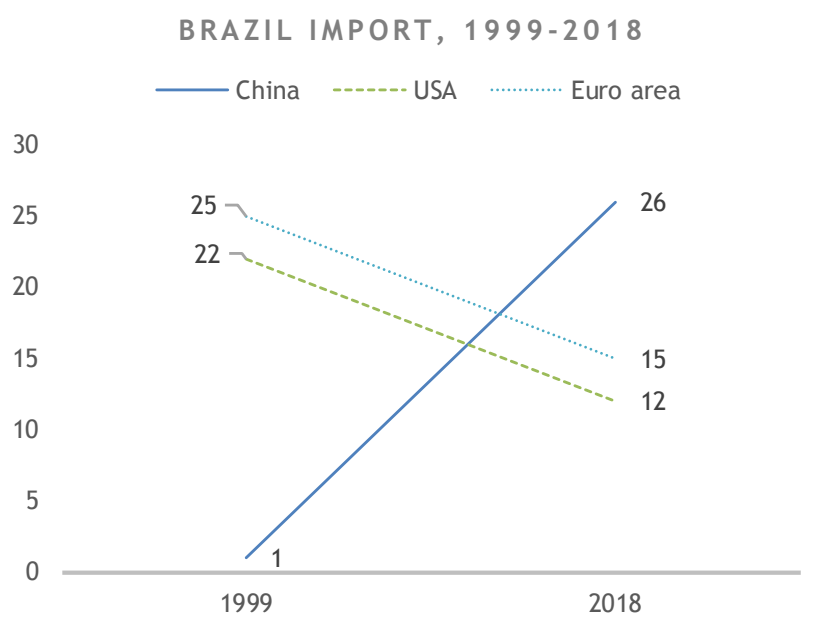

Fonte: elaboração própria a partir de Cysne (2019).

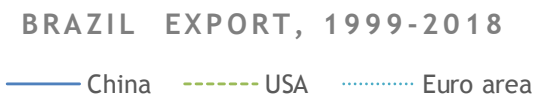

30

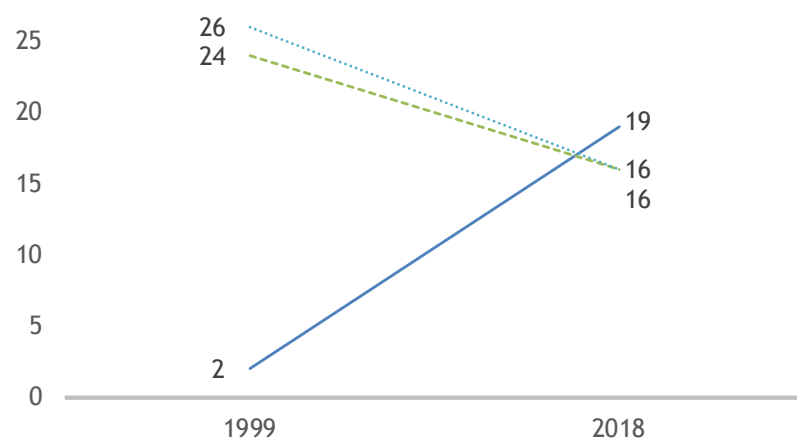

Essa tendência deve se intensificar com a escalada da guerra comercial EUA-China, uma vez que o Brasil está entre os países mais beneficiados. Depois que Pequim anunciou um imposto punitivo de $25 \%$ sobre os EUA, as exportações americanas de soja se reduziram pela metade, e o produto brasileiro compensou grande parte dessa redução (REN, 2019). O agronegócio corresponde a cerca de $60 \%$ das exportações brasileiras para a China, sendo a soja o principal produto, representando $70 \%$ do total da produção do agronegócio (CONSELHO EMPRESARIAL BRASIL CHINA, 2017).

As características dos produtos comercializados constituem o segundo aspecto de relevo do comércio internacional, principalmente no que diz respeito à diversificação e ao valor agregado. Nesse caso, o Brasil exporta para a China essencialmente produtos básicos, enquanto importa semimanufaturados e manufaturados (CYSNE, 2019). Essa questão contribui para o receio dos empresários brasileiros, e leva algumas indústrias a associarem o atual processo de desindustrialização que o Brasil vem sofrendo à relação comercial com a china. Além disso, o tópico é recor- 
rente em discussões oficiais e acadêmicas, intitulado "Ameaça à China" (ZHIWEI, 2019).

O Investimento Direto Estrangeiro (IDE) chinês no Brasil também desempenha um papel importante na relação bilateral, e foi impulsionado pelo bem-sucedido programa chinês Going Global, lançado em 1999.O programa assumiu como um dos seus objetivos estimular empresas chinesas a explorar mercados globais e direcionar sua economia, hoje orientada para o investimento em inovação.

A partir de 2007, a China começou a operar como um grande investidor estrangeiro no Brasil. Nesse ano, seu investimento foi inferior a US\$ 700 milhões. Todavia, como demonstra o gráfico abaixo, os investimentos anunciados e confirmados passaram de US\$14,5 bilhões em 2010 para mais de US\$ 19 bilhões em 2017.

Gráfico 3 - Investimentos chineses no Brasil, 2010 - 2017 (US\$ em bilhões)

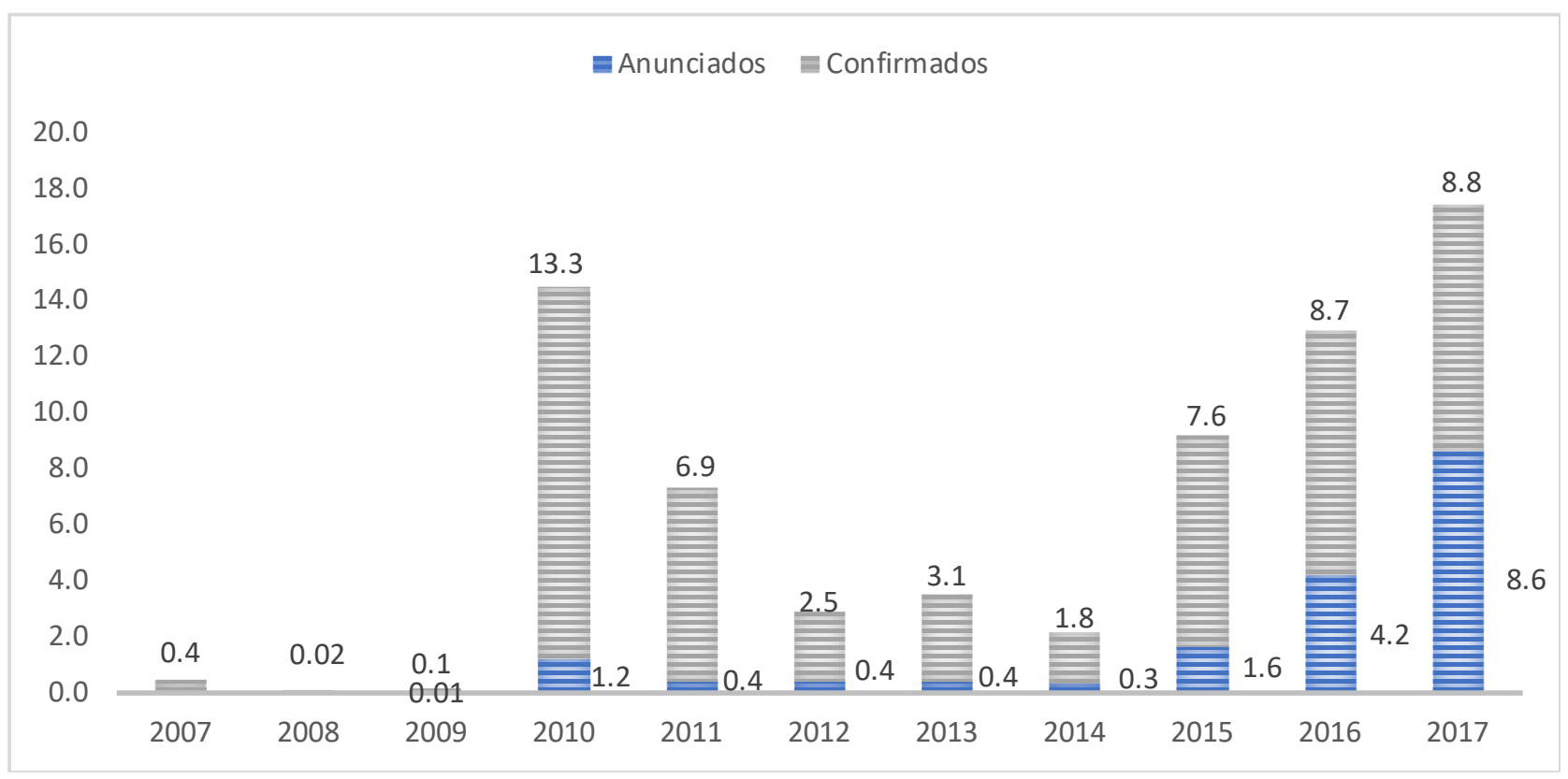

Fonte: Elaboração própria baseado nos dados de KUPFER, D.; ROCHA, F. (2018), CONSELHO EMPRESARIAL BRASIL CHINA (2013) e CONSELHO EMPRESARIAL BRASIL CHINA (2018).

Nos últimos 10 anos, as características desses investimentos vêm mudando, tanto quantitativamente quanto qualitativamente. Além da variação quantitativa mostrada acima, a análise do Conselho Empresarial Brasil China (CEBC) (2012-2018) classifica os investimentos em quatro períodos diferentes. Primeiro, em meados de 2000, quando o investimento chinês passou a ser relevante para o Brasil, o setor de commodities era o principal destino, com destaque para o petróleo, a soja e o minério de ferro. Esses ainda são os principais produtos importados pela China até agora, considerados essenciais para manter o intenso crescimento econômico chinês ${ }^{7}$ (CENTRO BRASILEIRO DE RELAÇÕES INTERNACIONAIS, 2020). Ademais, mais de $90 \%$ do investimento realizado em 2010 veio de empresas estatais centrais (State-Owned Enterprises - SOE) ${ }^{8}$, o que evidencia um interesse direto e de longo prazo do governo chinês.

7. Em 2018, dentre todos os bens exportados do Brasil para a China, $45 \%$ foram soja, $21.5 \%$ petróleo, e $16.6 \%$ minério de ferro. (Fonte: Ministério da Indústria, Comercio Exterior e Serviços)

8. "As Central SOE's representam um conjunto de 123 grandes corporações, pertencentes a setores estratégicos da economia chinesa e que estão sob a supervisão direta do governo central. Esta supervisão é feita pela Stated-OWned Assets Supervision and Administration Commission (SASAC), que consiste em uma instituição com status de ministério, autorizada pelo Conselho de Estado a assumir a responsabilidade de investidor do patrimônio estatal nas Central SOE's." (CEBC, pag. 7, 2012) 
9. A taxa de investimento público (em \% do PIB) em 2017 foi a menor desde de 1947 (PIRES, 2018)
A segunda fase teve início em 2010, com maior ênfase na exploração do mercado consumidor brasileiro e uma relativa diversificação de produtos. Os chineses investiram principalmente no setor industrial, como nos ramos automotivo, eletrônico, de equipamentos e máquinas (CONSELHO EMPRESARIAL BRASIL CHINA, 2018).

Por sua vez, a terceira fase se iniciou em 2013. Uma série de investimentos no setor de serviços passou a ganhar espaço, principalmente na área financeira, com a entrada de vários bancos chineses no país. Além disso, os investidores chineses fizeram um progresso notável na produção e transmissão de eletricidade. Empresas como State Grid e China Three Gorges Receberam importantes ofertas para a construção ou aquisição de usinas hidrelétricas e linhas de transmissão no país. O setor de agronegócio também desfrutou de investimentos significativos de empresas chinesas, principalmente por meio de aquisições globais. Pela primeira vez, as empresas privadas superam o investimento das públicas (CONSELHO EMPRESARIAL BRASIL CHINA, 2018).

Por fim, na fase mais recente, iniciada em 2015, houve uma concentração de investimentos em energia, infraestrutura e agronegócio, especialmente em grandes empresas chinesas que consolidaram sua presença no mapa energético brasileiro. As empresas públicas desempenham agora um papel decisivo, com $87 \%$ do valor investido (CONSELHO EMPRESARIAL BRASIL CHINA, 2018). Os investimentos em energia e infraestrutura merecem atenção especial, devido à importância estratégica dos setores para a soberania do país. A forma como esses investimentos são regulados pode implicar ganhos ou perdas de autonomia ou soberania no Brasil.

Nota-se, pelo cenário descrito acima, que o IDE da China está desempenhando papel importante no desenvolvimento econômico brasileiro, devido i) ao crescente montante de investimentos em um contexto de escasso recurso público'; e ii) aos setores estratégicos em que vem sendo empregado (energia e infraestrutura). Todavia, tais motivos também contribuíram para o aumento da vigilância sobre esses investimentos por parte do governo e empresas, e há uma crescente pressão para o endurecimento da proteção de indústrias estratégicas (ZHIWEI, 2019).

Já as motivações chinesas para o IDE vêm i)da arena política, no sentido de fornecer à China bens que o governo considera estratégicos para o seu desenvolvimento econômico, assim como para garantir a segurança energética e impulsionar a internacionalização do yuan; e ii)de fatores microeconômicos, com motivações econômicas devido à grande expertise chinesa em determinados setores. Tais investimentos buscam retornos financeiros e oportunidades competitivas de investimento.

Dessa forma, considerando o histórico de constante aproximação, a incorporação do Brasil à BRI parece quase uma extensão natural da relação entre os países. Entretanto, a complexidade inerente da BRI, a dinâmica político institucional brasileira e as mudanças na ordem mundial causadas pela ascensão da China colocam desafios que merecem ser explorados. As seções seguintes apresentam como esses desafios são abordados no contexto da mídia brasileira. 
China, Brasil e a Belt and Road Initiative

O governo chinês define a BRI como "uma política transcontinental de longo prazo e um programa de investimento que visa o desenvolvimento de infraestrutura e a aceleração da integração econômica dos países localizados ao longo da histórica Rota da Seda" (BELT AND ROAD INITIATIVE, 2019, tradução nossa). Criada em 2013, ela é considerada o mais ambicioso plano de cooperação da China, assim como um marco na transição do país para se tornar um ator ainda mais relevante na economia internacional (CENTRO BRASILEIRO DE RELAÇÕES INTERNACIONAIS, 2019).

O objetivo inicial era fortalecer grandes corredores econômicos. Esses corredores, inspirados na milenar Rota da Seda, incluíam Ásia do Leste, Central e Sul, assim como Europa e parte da África. Atualmente, o programa extrapola as dimensões geográficas da Rota da Seda, sendo que 71 países participam da BRI e já foram fechados acordos de cooperação intergovernamental com 143 países. Na América do Sul, Chile, Uruguai, Peru, Equador, Venezuela, Suriname, Guiana, Bolívia já participam do Programa (BELT AND ROAD PORTAL, 2019).

Além de promover conectividade física entre os países membros por meio de obras de infraestrutura, a BRI estabelece e fortalece parcerias em todas as dimensões, com objetivos econômicos e geopolíticos. As cinco prioridades de cooperação são a coordenação de políticas, a conectividade de infraestrutura, facilitação de comércio, a cooperação financeira e os laços interculturais (BELT AND ROAD INITIATIVE, 2019).

A título de ilustração da plasticidade do programa, diante da pandemia do COVID-19, o termo Health Silk Road, como uma extensão da BRI, vem sendo usado para designar as intensas ações bilaterais de ajuda médica aos países membros da iniciativa. Vale notar que esse termo já foi utilizado pelo governo chinês em 2017, estabelecendo que um dos objetivos do BRI seria melhorar a saúde pública dos países participantes. Uma iniciativa similar já evocou a Digital Silk Road para o setor de tecnologia (COUNCIL ON FOREIGN RELATIONS, 2019).

Se por um lado a definição ampla do escopo do programa e sua constante revisão, sempre com uma linguagem singular, permite a absorção e ajustes de várias agendas, por outro, esse é justamente um dos motivos que mantêm alguns países reticentes ao Programa, como ocorre no caso brasileiro.

\footnotetext{
Embora ambiciosa, a Iniciativa sofre críticas e questionamentos. As críticas são direcionadas, em sua maioria, à condução e gestão dos principais riscos da Iniciativa, entre eles: (i) a governança decisória dos investimentos, (ii) os níveis de endividamento dos países receptores e (iii) os impactos ambientais e sociais. Tais riscos são exacerbados pela limitada transparência da Iniciativa e pela frágil estrutura de governança dos principais países membros. (CENTRO BRASILEIRO DE RELAÇÕES INTERNACIONAIS, 2019, p. 27)
}

Cabe ressaltar que a BRI ainda é um tema bastante incipiente entre os pesquisadores brasileiros, especialmente porque, até o ano de 2018, a iniciativa chinesa era vista como restrita à região da Eurásia, despertando pouco interesse entre os acadêmicos e os demais atores que pautam o debate sobre a relação China-Brasil. Foi somente depois que o então Pri- 
meiro Ministro Chinês, Wang Yi, convidou os países latino-americanos a integrarem as iniciativas do BRI, durante o segundo Fórum China-CELAC, que a BRI começou a ser de fato debatida.

O documento " 45 anos de Relações Diplomáticas Brasil-China", que sintetiza as discussões do evento comemorativo realizado pelo CEBRI e Embaixada da China no Brasil, apresenta as perspectivas de ambos os países em relação ao BRI. Segundo o documento, a China "vê com bons olhos a participação do Brasil e da região na Iniciativa Cinturão e Rota" (CENTRO BRASILEIRO DE RELAÇÕES INTERNACIONAIS, 2020 , p. 7), e destaca a importância da parceria tanto para a retomada de investimentos no país, quanto para o fortalecimento e defesa dos arranjos multilaterais (CENTRO BRASILEIRO DE RELAÇÕES INTERNACIONAIS, 2020). Já na ótica brasileira, a relação bilateral é vista como madura e estável. Diante da ascensão da China como uma potência mundial, o país deverá traçar uma visão estratégica para guiar o aprofundamento dessa relação.

\section{A Belt and Road Initiative na mídia brasileira}

A BRI ainda desperta pouco interesse no Brasil. O Google Trends, por exemplo, mostra que entre os principais países Latino-Americanos (Brasil, Argentina, Chile e México), o Brasil é o que menos realizou buscas sobre o tema. México e Chile são, de longe, os países com maior número de buscas, seguidos por Argentina e Brasil, como ilustra o Gráfico 4.

Gráfico 4 - Google Trends sobre as buscas "One Belt one Road", "Nova rota da seda", "um cinturão uma rota" e "franja y ruta" no Brasil, Argentina, Chile e México, 01/2017 - 09/2019

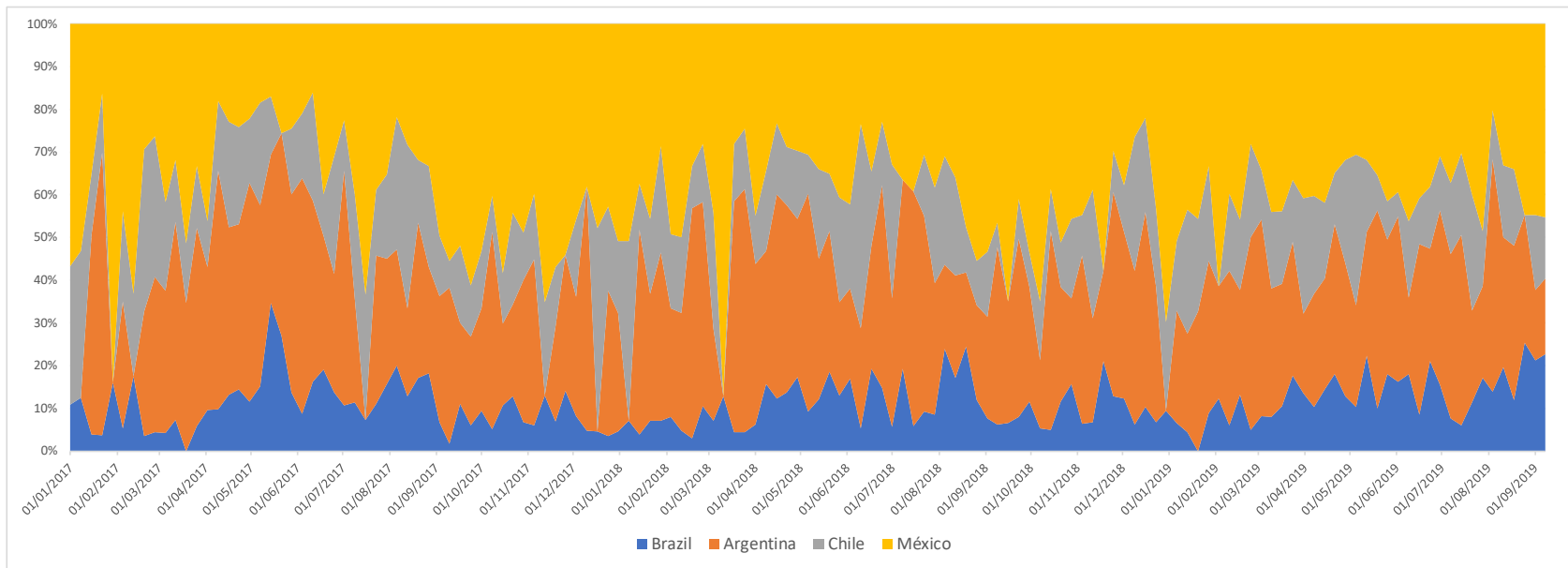

Fonte: Google Trends (2019)

10. Selecionamos as reportagens que contivessem alguma referência aos termos "rota da seda" e "um cinturão uma rota" (em português), ou "one belt one road" e "belt and road" (em inglês).
Para analisar como a BRI foi abordada pela mídia brasileira, adotamos os seguintes procedimentos. Na primeira etapa, coletamos todos os artigos/reportagens/colunas de opinião, entre os principais veículos de mídia do país, que tenham realizado alguma referência à BRI entre 2013 (ano em que o projeto veio a público pela primeira vez) e julho de $2019^{10}$. Esses veículos foram divididos de acordo com o pertencimento a 
um dos seguintes grupos: i) veículos de massa; ii) mídia especializada; e iii) mídia estrangeira.

Para o primeiro grupo, foram selecionados os dois principais veículos de massa com ampla circulação nacional, o jornal Folha de S. Paulo e o jornal $O$ Globo, pois constituem os dois jornais de maior circulação no país. Na mídia especializada, selecionamos o jornal Valor Econômico, que é o mais prestigiado e antigo veículo especializado em economia no país, e o Nexo Jornal. Lançado em 2015, o Nexo vem sendo reconhecido e premiado por sua excelência e formato moderno. Para a mídia estrangeira, selecionamos as reportagens veiculadas pela BBC Brasil, El País Brasil e Le Monde Diplomatique Brasil, representando os principais jornais estrangeiros com cobertura brasileira.

O gráfico 5 apresenta a distribuição das reportagens por ano e por veículo, sendo que foram coletadas ao todo 364 reportagens. O interesse pelo tema é crescente até 2015, quando cai em 2016. A partir de 2017, contudo, tem subido vertiginosamente e, como se pode observar, o número de reportagens até julho de 2019 (96) já é quase o mesmo do relativo ao longo do ano de 2018 (106), sendo razoável supor que será ainda maior ao final de 2019. Com respeito à veiculação do tema, vê-se que ele se concentra principalmente no Jornal Valor Econômico e nos jornais de grande mídia como Folha de São Paulo e O Globo, que juntos, são responsáveis por $318(87 \%)$ das reportagens.

Gráficos 5 e 6 - Evolução do número de reportagens com referência à BRl e veículo publicado, $2013-2019^{*}$

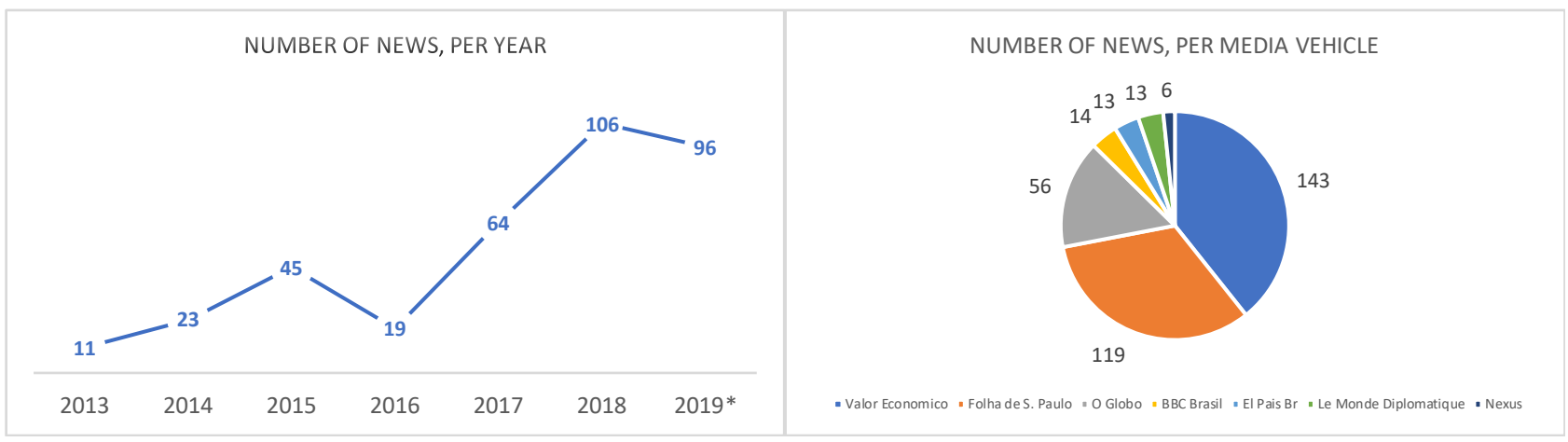

${ }^{*}$ Até julho/2019

Fonte: Elaboração própria.

Num segundo momento, realizamos uma análise preliminar das reportagens. Neste ponto, pudemos constatar que a maioria das reportagens veiculadas antes do ano de 2017 tratava do tema a partir do turismo pela antiga Rota da Seda. Ou, em algumas oportunidades, em referências ainda esparsas à iniciativa. Dessa forma, considerando que o volume de reportagens cresce a partir de 2017 após o Primeiro Fórum da BRI em Pequim, optamos por realizar uma análise aprofundada das reportagens veiculadas entre janeiro de 2017 e julho de 2019, somando um total de 266 reportagens. A análise do conteúdo das reportagens foi realizada por meio do software Iramuteq, a partir do método conhecido como Classificação Hierárquica Descendente (CHD) (RATINAUD, 2018). Este permite, 
através de sucessivas bipartições do corpus, agrupar as palavras segundo sua co-ocorrência vocabular, enquadrando os discursos em quadros mais amplos de descrição e valoração (MENEZES, 2019).

\section{Resultados da análise de conteúdo}

Como resultado, a CHD analisou 7.394 segmentos de texto, dos quais $87.57 \%$ foram aproveitados, com um total de 21.875 formas vocabulares e 264.104 ocorrências. Foram criadas ao todo 6 classes, conforme pode ser visto no dendograma e na tabela abaixo (figura 1). O dendograma apresenta a frequência e a proximidade das classes de palavras, ao passo que a tabela apresenta as principais palavras por ordem de importância.

O primeiro aspecto a se destacar é a característica principal dos grupos e como eles se aproximam. O principal assunto da Classe $4(13,4 \%$ das palavras) é a caracterização geral da BRI, enquanto a Classe 1 (23,3\% das palavras) trata das questões relativas à economia. A proximidade dessas duas classes no dendograma sugere que os assuntos costumam estar associados, como era de se esperar.

Já as classes $2(18,4 \%)$ e $3(21,0 \%)$ lidam com questões internacionais, mas de forma distinta. A Classe 2 é claramente voltada para assuntos relacionados à disputa de poder internacional, enfatizando o modo pelo qual a BRI se insere nesse contexto. Já a Classe 3 se dirige à política internacional em um sentido mais amplo. Essas duas classes estão fortemente conectadas. Associada a elas, mas em menor grau, se encontra a Classe $5(12,4 \%)$, que lida de forma específica com a política brasileira e suas relações internacionais. Finalmente, a Classe 6 (11,5\%), a menor dentre as classes, se mostra mais dispersa e isolada do que as demais, por tratar especificamente dos assuntos internos à China, como aqueles relacionados à província de Xinjiang e Hong Kong. 
Figura 1 - Dendograma e tabela: Frequência e associação das classes de palavras e principais palavras em cada classe

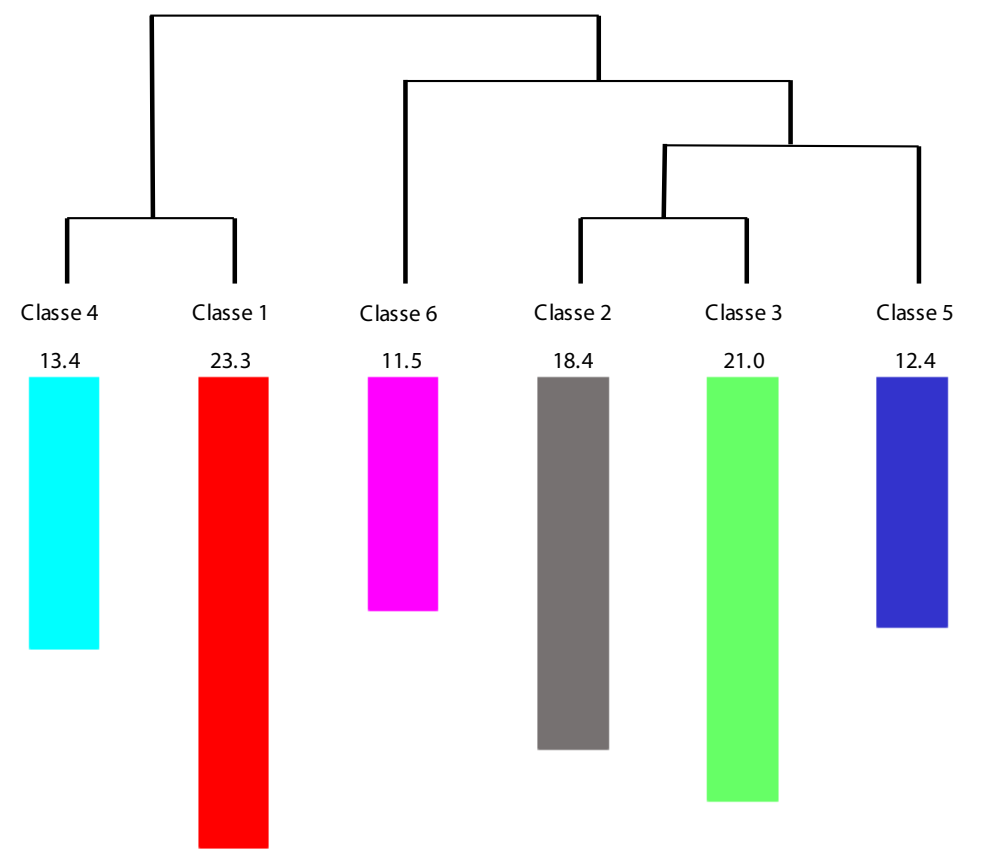

\begin{tabular}{|c|c|c|c|c|c|c|}
\hline Classe & Classe 4 & Classe 1 & Classe 6 & Classe 2 & Classe 3 & Classe 5 \\
\hline $\begin{array}{l}\text { Tópico e } \\
\text { palavras } \\
\text { principais }\end{array}$ & $\begin{array}{c}\text { Caracterização } \\
\text { e descrição do } \\
\text { B.R.I. }\end{array}$ & $\begin{array}{c}\text { A economia do } \\
\text { B.R.I. }\end{array}$ & $\begin{array}{l}\text { Questões } \\
\text { internas } \\
\text { Chinesas }\end{array}$ & $\begin{array}{l}\text { Geopolitica e } \\
\text { relação de } \\
\text { poder }\end{array}$ & $\begin{array}{c}\text { Relações } \\
\text { internacionais }\end{array}$ & $\begin{array}{l}\text { Política } \\
\text { brasileira }\end{array}$ \\
\hline 1 & Rota & Empresas & Hong Kong & Coréia do Norte & Global & Hamilton Mourão \\
\hline 2 & Seda & Mercado & Muçulmano & Guerra & Liderança & Presidente \\
\hline 3 & Infraestrutura & Débito & X injiang & Estados Unidos & Política & Jair Bolsonaro \\
\hline 4 & Cinturão & Energia & Mao Zedong & Donald Trump & Economia & Visita \\
\hline 5 & Initiativa & Exportação & Uighurs & Rússia & Universidade & Encontro \\
\hline 6 & Projeto & Produto & Pessoas & Americanos & Poder & Reunião \\
\hline 7 & Estrada & Crescimento & Protesto & Militar & International & Ministro \\
\hline 8 & Trem & Banco & Mesquita & Aliança & Mundo & Relação \\
\hline 9 & Porto & Setor & Mulher & Japão & Sistema & Cosban \\
\hline 10 & África & Gás & Minoria & Nuclear & Governança & Chanceler \\
\hline 11 & Ásia & Crédito & Religião & Comercial & Reforma & Oficial \\
\hline 12 & Notícia & Financeiro & Família & Ameaça & Soft Power & Angela Merkel \\
\hline 13 & Investmentos & Produção & Revolução & Europe & Cenário & Kim Jon Um \\
\hline 14 & Construção & Vendas & Partido & Sanção & Nacional & Comissão \\
\hline 15 & Autoestrada & Investmentos & Islamismo & Tensão & Breton Woods & Vladimir Putin \\
\hline 16 & Marítimo & I mportação & Étnico & Moscou & Defesa & Viajar \\
\hline 17 & BRI & Reservas & $\begin{array}{l}\text { Direitos } \\
\text { Humanos }\end{array}$ & Sul & Definir & Entrevista \\
\hline 18 & Europa & Taxa de juros & Política & Rivalidade & Globalização & Macron \\
\hline 19 & Finança & Preço & Raça & Austrália & Vácuo & Dilma \\
\hline 20 & Ambicioso & Consumo & Ilegal & União & Muro & Panamá \\
\hline 21 & Inglês & Fiscal & Terrorismo & Otan & Congresso & Argentina \\
\hline 22 & Desenvolvimento & Redução & Noroeste & Huawei & Ideologia & Índia \\
\hline 23 & Programa & Aquisição & Extremismo & Mar & Comunismo & Brasília \\
\hline
\end{tabular}

Fonte: elaboração própria 
A nuvem de palavras abaixo (Figura 2) permite uma visualização complementar das classes, dando-lhes maior sentido interpretativo. Em primeiro lugar, é importante ressaltar que o tamanho da "nuvem" não diz respeito exatamente ao tamanho da classe. Vê-se, por exemplo, que apesar da classe 6 (rosa) ocupar o maior tamanho na nuvem, ela é a menor de todas as classes, com apenas $11,5 \%$ das ocorrências. Por outro lado, a classe 2 (cinza) que ocupa o menor espaço na nuvem de palavras, é a terceira maior classe, com $18,4 \%$ dos casos. Isso significa que a classe 2 é muito mais homogênea internamente do que a classe 6.

Figura 2 - Nuvem de palavras geradas a partir das reportagens com referência à BRI

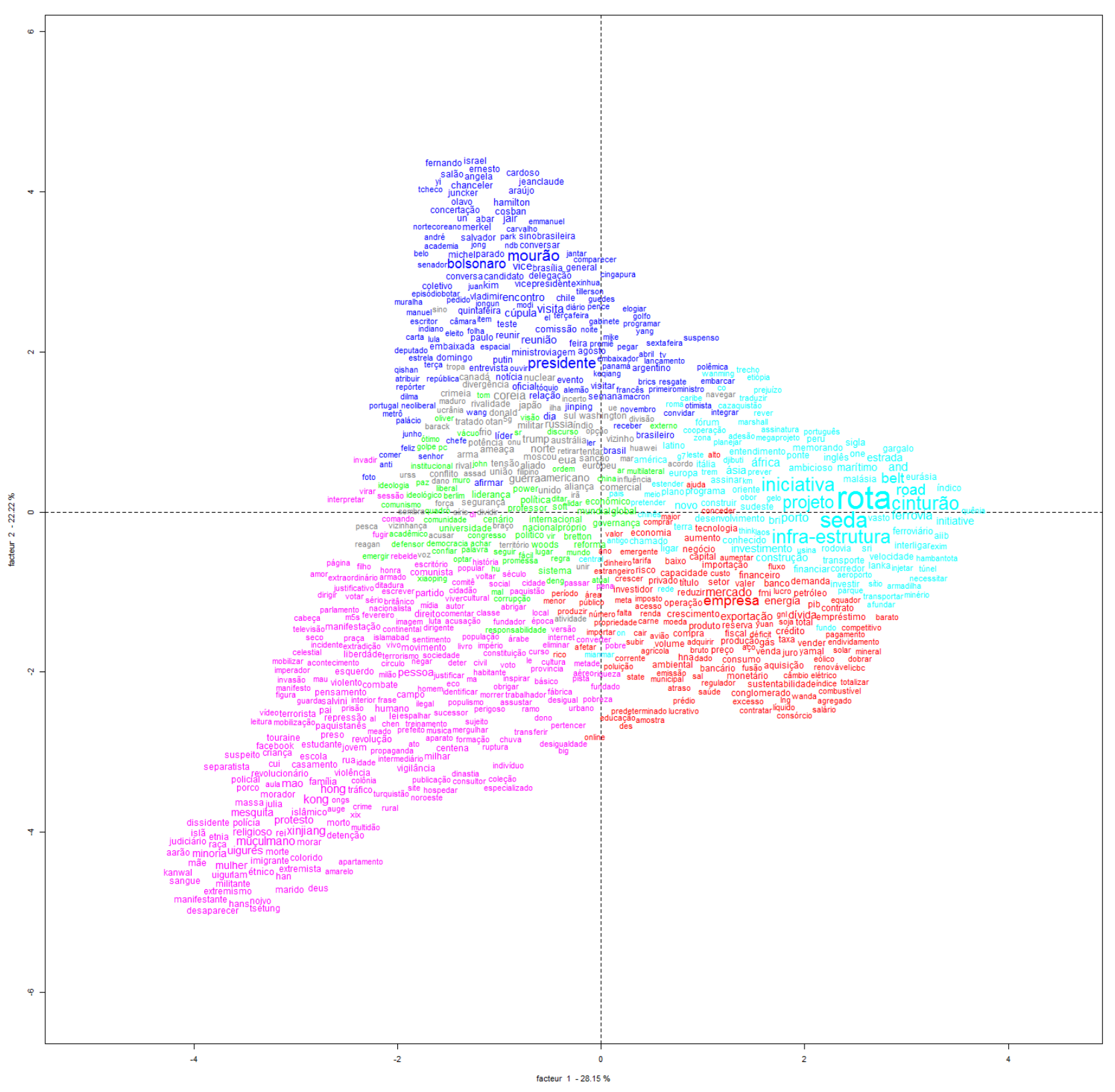

Fonte: Elaboração própria. 


\section{Classes 4 e 1: Caracterização e descrição da BRI}

A classe 4 trata principalmente da descrição da BRI, considerando suas principais características, um pouco do histórico e alguns dos países e projetos que já fazem parte da iniciativa. As principais palavras destacadas, "iniciativa", "Rota da seda" e "projeto" se encontram exatamente no meio do espaço gráfico, dividindo outros dois grupos de palavras. Mais acima, ganham destaque as regiões e os países onde a BRI já possui ações efetivas, como por exemplo, "África”, "Ásia”, "Europa", "Cazaquistão", "Etiópia". E logo abaixo, palavras que estão semanticamente ligadas à palavra "infraestrutura", como "transporte", "aeroporto", "investimento", "porto", "projeto" e "desenvolvimento". Esta Classe de palavras informa que a imprensa brasileira apresenta o BRI como um "ambicioso" projeto de infraestrutura, com destaque especialmente à área de transporte e logística. Por outro lado, chama atenção como nenhuma outra forma de infraestrutura é citada em tais relatos, como se a BRI se limitasse a construir estradas, linhas de trem e aeroportos. A passagem abaixo é um típico exemplo desse grupo:

Está se lançando em um ambicioso projeto, de dimensões planetárias, a chamada Nova Rota da Seda, que terá trens de alta velocidade ligando a China à Europa, portos modernos e novas rotas marítimas ligando a costa da Ásia à África, depois chegando à Europa e às Américas (pelo Atlântico e pelo Pacífico)" (MEDEIROS FILHO, 2018).

Em forte associação com a Classe 4, encontra-se a Classe 1. Mas se a Classe 4 se refere principalmente a uma descrição básica da BRI, a Classe 1 apresenta um conteúdo mais analítico, com destaque para três temas em especial.

O primeiro deles se refere ao chamado debt-trap diplomacy, ecoando as inúmeras críticas realizadas por especialistas, chefes de estado e ministros de países do Ocidente, principalmente, mas também de outros países (CARMINATI, 2019). Nesse sentido, sugerem que a BRI representa uma estratégia para obter influência política em países economicamente vulneráveis, através de empréstimos que são impossíveis de serem quitados. Como não poderia deixar de ser, o caso do porto de Hambantota em Sri Lanka é o mais emblemático, e sempre é citado como uma justificativa para a necessidade de cautela para a incorporação dos países à BRI. A passagem abaixo é bastante ilustrativa de como esse tema aparece na mídia brasileira.

Os mais críticos da iniciativa falam da armadilha do endividamento como algo intrínseco à BRI como se a China desejasse transformar os parceiros em devedores com o objetivo deliberado de exercer maior influência sobre eles. [...] Para além da questão da influência política, analistas se preocupam com a falta de transparência dos projetos relativos à Belt And Road Initiative e o alto endividamento que geram. Segundo algumas avaliações, isso torna uma série de países, especialmente nações pequenas, sem acesso ao sistema internacional de crédito praticamente reféns de dívidas milionárias com a China. Isso porque os projetos são geralmente financiados por empréstimos junto ao Estado chinês ou a instituições semi-estatais chinesas. [...] Para muitos países isso tem a ver com uma avaliação do endividamento e da sustentabilidade dessas dívidas. E aí não fica tão claro se há um benefício líquido para alguns países. Praticamente todo o financiamento da BRI é feito por empréstimos e não por ajuda financeira, e não está claro no caso de muitos países se eles têm a capacidade para assumir tais dívidas, 
explicou. Djibuti, por exemplo, viu sua dívida externa pública aumentar de 50 para 85 do PIB em dois anos, segundo o FMI. A maior parte dessa dívida é com o China Exim Bank. A China ainda pretende construir no país africano um porto, um terminal petrolífero e uma estrada ligando Djibuti a Addis Abeba, na Etiópia. Uma das nações mais pobres da Ásia, apesar do crescimento de em média 8 por ano na última década, o Laos tem quase metade do seu PIB US 6 bi empenhada numa ferrovia que o liga à China. No Paquistão, 80 dos US 62 bilhões do custo estimado para o CEPC são financiados pela China. Devido ao alto endividamento, o país já cancelou projetos ligados ao BRI e pediu créditos ao FMI. Em 2011, a China concordou em perdoar uma parte da dívida do Tadjiquistão em troca de uma área de $1.158 \mathrm{~km}^{2}$ em território disputado. Autoridades do país asiático dizem que cederam apenas 5,5 das terras que Pequim queria. O Sri Lanka contraiu uma dívida de US 8 bilhões a uma taxa de juros de 6 para a construção do porto de Hambantota. Em julho de 2017, Pequim concordou em fazer um swap (troca) da dívida com um contrato de arrendamento de 99 anos para administrar o porto (VILA NOVA, 2019)

Essa visão, contudo, é por vezes contrastada com o fato de que a China tem reconhecido que ela mesma pode se tornar vítima do seu próprio debt. Portanto, também tem sido destacado, embora em menor escala, os ajustes que o governo chinês pretende fazer de modo a evitar esse problema. O principal argumento exposto é o de que quanto mais a China investe em um determinado país, menor será o seu poder de barganha, aumentando a pressão por renegociação por parte do país credor.

\footnotetext{
Como essas empresas são controladas pelo governo da China, podem acumular dívidas enormes sem medo de quebrar. Isso, porém, está começando a mudar e de forma que pode afetar os investimentos na BRI. Em maio, Pequim deu prazo até 2020 para que as empresas da Sasac reduzam os percentuais da dívida em relação aos ativos. Analistas dizem que isso provavelmente implicará num maior foco na qualidade dos projetos de investimento no exterior. [...] Isso significa que a [questão da] sustentabilidade da dívida será observada cada vez mais de perto, particularmente nos países de alto risco ao longo da Nova Rota da Seda. Alguns investimentos na BRI considerados demasiado arriscados podem ser abandonados, e o volume de novos investimentos pode diminuir, segundo disse a alta autoridade chinesa (KYNGE, 2018)
}

Por fim, ainda nesse quesito, ganham ênfase os investimentos e as oportunidades em energia da BRI. Por um lado, dá-se muito menos destaque ao acordo entre China e Rússia com respeito à Usina Yamal LNC, e como este configura um exemplo da participação chinesa na distribuição de energia pelo globo. Por outro, embora em menor escala, discute-se que a participação do Brasil na BRI poderia alavancar a utilização de energia renovável no Brasil, área em que a China exerce uma liderança mundial.

Em síntese, pode-se perceber que a mídia brasileira tende a realizar uma apresentação bastante descritiva e neutra da BRI, destacando um pouco do seu histórico e das principais iniciativas em curso até o momento. Logo após, busca-se uma visão com características mais analíticas, que reverbera a visão de especialistas sobre o tema e, em alguns momentos, também da imprensa internacional - em especial da imprensa ocidental. Nesse caso, o tema do debt-trap aparece como a principal crítica e um possível ponto negativo, embora seja ressaltado que a própria China tem tomado iniciativas de modo a evitar que essa visão se difunda e se cristalize entre os possíveis parceiros. Por fim, destaca-se como, além dos investimentos em infraestrutura, os investimentos em energia - especialmente em energia renovável - constituem um aspecto através do qual o Brasil poderia se beneficiar caso aderisse à BRI. 
Classes 3 e 2: A política da BRI - relações internacionais e conflitos de poder

As Classes 2 e 3, que juntas são responsáveis por aproximadamente $40,0 \%$ das referências, lidam com questões relativas à política da BRI, sendo que a primeira se atém aos temas mais relacionados à disputa de poder pela hegemonia da ordem mundial, e a segunda à descrição da BRI dentro do quadro mais geral das relações internacionais.

As principais palavras da Classe 2 são bem elucidativas: "guerra", "Estados Unidos", "Donald Trump", "Rússia", "aliança” e "militar". Vale notar que a Classe 2 (cinza) ocupa um espaço bastante reduzido na nuvem de palavras, embora represente $18,4 \%$ das ocorrências. Isto sugere que a abordagem do tema é bastante homogênea, com poucos dissonantes de significado. Basicamente, trata-se de enquadrar a BRI na geopolítica mundial, mas destacando também como a iniciativa está intimamente relacionada à distribuição de poder no mundo, seja econômico, político ou militar. Nesse caso, vale a pena ressaltar que, com base nas palavras mais frequentes, a mídia brasileira ressalta o fato de que a BRI está longe de ser apenas um projeto econômico.

O principal ponto de destaque neste grupo se refere ao modo como a BRI faz parte do movimento de aproximação entre Rússia e China, em oposição aos Estados Unidos, tanto no que diz respeito à esfera econômica quanto no que diz respeito à cooperação militar e aeroespacial. Nesse caso, faz-se muita referência ao fato de que a aproximação é também um resultado indireto da política externa errática dos Estados Unidos, com crítica especial à figura de Donald Trump. A BRI é vista, assim, como um projeto que se beneficia largamente da inclinação protecionista e da posição antiglobalização do presidente norte americano.

\begin{abstract}
A segurança e a luta contra o terrorismo islâmico na Ásia Central, região que a China prevê como uma das grandes áreas de expansão de seu ambicioso plano de infraestrutura conhecido como Nova Rota da Seda, compõem outro eixo das conversações bilaterais dos dois líderes e das multilaterais no foro, do qual participarão os chefes de Estado ou de Governo dos principais países dessa região. Em sua reunião formal, XI e Putin assinaram acordos de cooperação, entre eles o estabelecimento de um fundo de investimento industrial dotado de 1 bilhão de dólares ( 3,7 bilhões de reais) e a construção, pelos russos, de quatro centrais nucleares em território chinês. Os dois países querem estimular também sua relação comercial, que ainda está muito longe de alcançar a meta oficial de 200 bilhões de dólares (742 bilhões de reais) para 2020. A lógica do comércio mundial é a cooperação conjunta, disse o presidente chinês. Desta vez, suas palavras não foram dedicadas a seu amigo. Era uma mensagem dos dois a Trump. Acordos, acordos e mais acordos. Os acordos firmados pelos dois presidentes se estenderam também à agricultura, tecnologia e aeronáutica (LIY, 2018)
\end{abstract}

Ainda nesse quesito, a questão militar aparece como uma estratégia latente da BRI, independente da aliança com a Rússia. Para alguns analistas, os portos no Sri Lanka e no Paquistão, os oleodutos e gasodutos que atravessam a Ásia Central e a base militar instalada no Djibouti são iniciativas que se enquadram na estratégia de afirmação da China enquanto potência geopolítica e militar.

Essa base no Djibouti representa a extensão natural dos interesses em expansão e da missão de segurança da China na região e sinaliza as cada vez maiores ambições globais chinesas. Pode ser compreendida no contexto da chamada estratégia do colar de pérolas: o estabelecimento de uma rede de ativos militares 
e comerciais ao longo do Oceano Índico de modo a projetar poder no exterior o que eventualmente pode gerar tensões com a Índia, cujas disputas fronteiriças com a China, no Himalaia, estão ocupando as notícias internacionais. Em um panorama mais amplo, a instalação no Chifre da África também pode ser entendida no quadro da iniciativa chinesa One Belt, One Road [um cinturão, uma rota] ou a nova Rota da Seda, a criação de eixos de infraestrutura terrestre e marítima da Ásia ao Mediterrâneo (CHARLEAUX, 2017).

Como pode ser visto na nuvem de palavras, as classes 2 e 3 estão muito próximas uma da outra. A principal diferença entre elas reside no fato de que a Classe 3 lida mais com a questão do arranjo da ordem mundial em si mesma, sem tantas menções à questão militar. Nesse ponto, fica muito claro como a imprensa brasileira percebe o avanço chinês como preenchendo um certo vácuo deixado pela política protecionista de Donald Trump. Mais do que isso, há uma visão generalizada de que, apesar de um sistema socialista, a China é hoje o principal defensor do liberalismo no comércio internacional.

Pequim avança para ocupar a lacuna que o novo protecionismo norte americano deixará. Em uma das últimas atividades do Governo chinês antes da pausa para o Ano Novo lunar, o primeiro ministro, Li Keqiang, falou por telefone com a chanceler alemã Angela Merkel. A mensagem: que ambos os países devem garantir a estabilidade do sistema econômico internacional diante dos atuais momentos de incerteza no mundo. Tempos que se precipitaram com a chegada à Casa Branca de Donald Trump e que abriram uma oportunidade para que Pequim se posicione como baluarte da ordem mundial. O presidente Xi Jinping já tinha assentado as bases, em seu discurso em Davos apenas três dias antes da posse de Trump em Washington, quando lançou uma defesa acalorada da globalização econômica, do livre comércio e da luta contra a mudança climática. E o próprio Li defendeu, em um artigo para a Bloomberg Businessweek, que a China oferece uma âncora de estabilidade e crescimento com sua mensagem consistente de apoio às reformas, abertura e livre comércio. Continuamos convencidos de que a abertura econômica beneficia a todos, em casa e no exterior. Durante seu mandato, Xi Jinping se tornou um dos líderes chineses que mais viajou na história recente do país. Em momentos em que a ONU pareceu desgastada, ofereceu apoio, financiamento e tropas. Foi anfitrião da reunião anual do G 20, propôs novos acordos comerciais, criou um novo banco de desenvolvimento o BAII e quer desenvolver uma rede de infraestrutura que conecte a China ao Ocidente (LIY, 2017).

Há, entretanto, grandes ressalvas quanto ao fato de que a China ainda representa algo "desconhecido" para o Ocidente, uma visão, por sinal, bastante difundida no Brasil. Isso causa uma certa suspeição com respeito às reais intenções da China, tanto quanto potência global, em sentido amplo, como também no que diz respeito à BRI, mais especificamente. A passagem abaixo, de março de 2019, é bastante ilustrativa:

Mas talvez a maior dificuldade que os chineses têm à frente seja a de lidar, especialmente fora de sua área de influência imediata, com a resistência ao desconhecido, com o desconforto com o diferente e com a desconfiança em relação às intenções chinesas e ao modo de a China operar. A realidade é que o mundo ainda está se adaptando à emergência da China como potência mundial, como pólo alternativo de poder. Esse possivelmente é o principal desafio para as ambições globais da BRI. Os objetivos da diplomacia econômica chinesa se assemelham aos das potências tradicionais, como EUA e União Européia, em relação aos quais a resistência costuma ser muito menor. Naturalmente, a China tem sua própria visão de mundo, tem sua maneira de atuar o que não é ruim em si, mas é distinto e isso causa suspeição. Apesar do rápido avanço da BRI, ainda está em curso a missão de convencer o mundo de que a iniciativa interessa efetivamente aos parceiros, e não apenas à China (PRAZERES, 2019). 


\section{Classe 5: A BRI na politica brasileira}

Dentre as reportagens analisadas, a primeira vez que a BRI foi apontada como um projeto do qual o Brasil poderia participar foi em uma artigo publicado pelo Le Monde Diplomatique Brasil em 12 de junho de 2017, intitulado "A nova rota da seda e o Brasil". O artigo limita-se a descrever a BRI, mas já antevê como o Brasil poderia se beneficiar no futuro.

No mínimo, é fundamental que atores brasileiros acompanhem de perto os debates e as iniciativas associadas. Mas um engajamento mais institucionalizado e estratégico daria ainda mais peso a essa participação. Uma comissão interministerial, com representantes de diversos órgãos que lidam com planejamento econômico e de política externa, ajudaria a garantir a presença brasileira e a fortalecer a participação substantiva nos principais debates acerca do Obor. Por meio do Novo Banco do Brics ou se vier a tornar se sócio do AIIB, o Brasil também deve participar dos debates normativos acerca da iniciativa e do modelo de desenvolvimento que ela busca promover. Da mesma forma, a sociedade civil deve engajar se nas discussões, fomentando pesquisas e debates sobre o assunto através do setor privado, de centros de pesquisa e de ONGs. Em um mundo cada vez mais multipolar, o Brasil não pode se dar ao luxo de ficar de fora das principais discussões e iniciativas geopolíticas (ABDENUR; MUGGAH, 2017).

O tema não continuou chamando muita atenção da mídia brasileira até janeiro de 2018, quando, por ocasião do Fórum China-CELAC, em Santiago do Chile, foi formalizado o convite para que os países latino-americanos integrassem a BRI. Entretanto, o convite chinês não despertou muito interesse nem dos países latino-americanos (PIRES, 2019) nem da imprensa brasileira.

Foi somente em maio de 2019, durante a visita à China do vice-presidente brasileiro Hamilton Mourão, que o tema de fato ganhou os jornais. Não por acaso, é possível ver que a Classe 5 de palavras tem o nome do vice como a mais recorrente, seguida pelo nome do próprio presidente, Jair Bolsonaro.

No Brasil, a visita do vice-presidente foi considerada como uma importante tentativa de minimizar os efeitos das polêmicas declarações do Presidente Jair Bolsonaro, então candidato, durante a campanha presidencial de 2018. Naquele contexto, com um discurso fortemente inclinado a um populismo nacionalista de direita, Bolsonaro afirmou diversas vezes que a China não estava comprando do Brasil, mas sim "comprando o Brasil", e que as relações bilaterais entre os dois países precisavam ser revistas (SPRING, 2018).

As declarações do presidente com relação à China causaram apreensão, seja por parte dos analistas econômicos, que reconhecem a enorme importância da China para a economia brasileira, seja por parte dos setores que exportam para a China, especialmente os representantes do agronegócio. Não por acaso, o editorial do China Daily "No reason for 'Tropical Trump' to disrupt relations with China”, em 29 de outubro de 2018, causou grande alarde no Brasil. Naquela ocasião, a mensagem de Pequim soou como um claro e ameaçador recado às intenções do presidente eleito em seguir a linha radicalizada de Donald Trump:

Boicotar a China, que Bolsonaro descreveu como um parceiro excepcional, pode servir a algum propósito político específico. Mas o custo econômico pode ser difícil para a economia brasileira, que acaba de emergir de sua pior recessão da história"11 (CHINA DAILY, 2018, tradução nossa).
11. Dumping China, whom Bolsonaro once described as an exceptional partner, may serve some specific political purpose. But the economic cost can be backbreaking for the Brazilian economy, which has just emerged from its worst recession in history. 
O fato é que a visita de Hamilton Mourão à China e o encontro com o Presidente Xi Jinping em maio de 2019 parece ter retomado a normalidade e melhorado as perspectivas das relações entre os países. Mais simbólico do que efetivo do ponto de vista da assinatura de acordos (CARIELLO, 2019), o encontro serviu para preparar o terreno para uma futura visita do presidente Jair Bolsonaro, ainda em 2019, para reativar a COSBAN, suspensa desde 2016.

Nesse encontro, a China oficializou o convite para a integração brasileira à BRI, e foi a partir daí que o tema de fato passou a despertar interesse como algo que possa afetar o Brasil diretamente. Desde então, a imprensa brasileira tem tratado do tema com cautela e, embora destaque as oportunidades que possam surgir de um possível acordo, ressalta dois pontos em especial. O primeiro é que a BRI tem inclinações geopolíticas e o Brasil deve estar atento para este fato, especialmente considerando sua posição de proximidade com os Estados Unidos. O segundo atenta para o fato de que a adesão do Brasil à BRI não significa, automaticamente, receber um "cheque em branco" de investimentos.

\begin{abstract}
Setores no Brasil notam que uma participação brasileira não significaria ganhar um cheque a ser descontado logo para investir em infraestrutura. O programa tem motivações geopolíticas e econômicas. O mais importante é a parte política, com Pequim querendo dar demonstração de força e influência, como ocorreu ao obter a entrada da Itália o primeiro país, neste caso, do G7, grupo dos maiores industrializados, o que causou divisão entre os europeus. Para certos observadores da cena bilateral, com ou sem Nova Rota da Seda, o investimento chinês continuará a tomar o rumo do Brasil quando Pequim identificar oportunidades no país. Em setores da academia no Brasil, uma participação brasileira na Nova Rota da Seda é vista de forma favorável, para maior integração do país no exterior e sem alterar a relação com Washington. Fontes do segmento notam que o Brasil precisa estar atento também à participação no programa americano pelo qual a Casa Branca tenta se contrapor à iniciativa chinesa. Xi Jinping promove uma visão mais assertiva da China e, no cenário de um novo padrão de crescimento global menor, busca conquistar mercados para seus produtos de consumo e reduzir o excesso de capacidade industrial do país. (MOREIRA, 2019).
\end{abstract}

Vale destacar, por fim, uma entrevista concedida pelo Vice Presidente Hamilton Mourão ao jornal Valor Econômico, logo após a sua viagem oficial à China, em maio de 2019. Nessa oportunidade, Mourão revelou que a prioridade da viagem foi reativar a COSBAN, mas também revelou sua visão sobre a "agressividade chinesa" nos negócios.

Primeiro que a Cosban [Comissão SinoBrasileira de Alto Nível de Concertação e Cooperação] voltasse a funcionar, porque estava há quatro anos parada. A ideia é realmente colocá-la como mecanismo de mais alto nível, em que haja um filtro de todo esse relacionamento, porque os chineses são muito agressivos. Eles vão em governo estadual, vão em ministério e muitas vezes a gente não tem controle e não sabe o que está acontecendo (ARAÚJO; RITTNER; MURAKAWA, 2019).

Posteriormente, quando indagado se o Brasil iria aderir à BRI, voltou a demonstrar certo incômodo com a agressividade chinesa, mas destacou que o Brasil considera aderir à BRI desde que se encaixe nas suas prioridades e necessidades.

Os chineses hoje estão muito impositivos em cima dessa questão da Belt And Road Initiative [conhecida também como Nova Rota da Seda]. É quase uma laçada que eles te dão para te deixar, vamos dizer assim, alinhados às necessidades chinesas. A orientação do presidente era que a gente não desse um sinal positivo, ficasse com um sinal de que nós consideramos a Belt And Road, mas queremos que ela se adapte às nossas necessidades, e não única e exclusivamente às da Chi- 
na. Em uma guerra comercial, a gente tem que explorar as oportunidades, temos que ser flexíveis e pragmáticos (ARAÚJO; RITTNER; MURAKAWA, 2019).

Um último ponto da entrevista que merece ser mencionado é quando ele foi indagado sobre como o Brasil poderia participar da BRI sem cair no debt-trap. Nesse ponto, o vice-presidente destacou que

\begin{abstract}
O que a gente tem que evitar é o seguinte: quero emprego gerado aqui, não aquele [projeto] que o cara traz 100 mil chineses para trabalhar no Brasil. O que queremos nessa questão? Vamos falar especificamente de investimento. Nós precisamos de investimento em infraestrutura. Aquilo que for de infraestrutura e que vai beneficiar o comércio com a China é um investimento bom que atende o interesse dos dois países (ARAÚJO; RITTNER; MURAKAWA, 2019).
\end{abstract}

Desde então, o tema da BRI tem aparecido pouco na mídia brasileira ou, quando muito, como algo relacionado à guerra comercial entre a China e os Estados Unidos. Apesar do tema ter voltado à pauta após os encontros oficiais agendados entre o Presidente brasileiro Jair Bolsonaro e o Presidente chinês Xi Jinping - um em outubro de 2019 na China e o outro em novembro de 2019 no Brasil, durante a Cúpula dos BRICS - pouco se avançou nessa discussão.

\title{
Sintese dos resultados
}

A mídia brasileira ainda tem uma visão relativamente neutra, embora positiva, com relação à BRI. De modo geral, tende a descrevê-la como um grande projeto de infraestrutura que se insere no quadro das ambições chinesas de afirmação enquanto potência mundial. Ao mesmo tempo, reverbera parte das críticas que ecoam na imprensa internacional ocidental, especialmente aquelas que dizem respeito ao debt-trap. É interessante observar, contudo, a ausência de outro ponto de vista bastante presente nas análises internacionais, qual seja, a de que a BRI nada mais é do que uma estratégia Chinesa para garantir o fluxo de recursos naturais para o seu território.

Quanto à possível incorporação do Brasil à BRI, a imprensa mantém a inclinação positiva, conquanto cautelosa. Além das críticas mais gerais ao projeto, o fator geopolítico e o posicionamento do Brasil frente à disputa pelo poder internacional entre Estados Unidos e China são os principais temas abordados.

Discussão

As análises apresentadas no presente trabalho demonstram que, embora haja uma inclinação para uma visão positiva da BRI, a iniciativa chinesa ainda não é muito conhecida no Brasil. Na mídia, o interesse vem crescendo, mas é ainda tratado de forma superficial e sem explorar todo o seu potencial - na maioria das vezes, as reportagens se limitam a descrever a BRI como um pacote de investimentos em infraestrutura.

Por se tratar de uma democracia pluralista e multipartidária, o sucesso de grandes iniciativas no Brasil depende em larga medida do grau de consenso em torno dos temas, seja nas arenas formais de decisão, seja junto à opinião pública. O elevado grau de desconhecimento sobre a BRI, portanto, configura uma especial oportunidade para iniciativas que bus- 
12. Segundo declaração do governador de São Paulo em agosto de 2019, "São Paulo reúne condições para se tornar um ponto de vanguarda da Nova Rota da Seda, o movimento de abertura e integração promovido pelo governo do presidente Xi Jinping (DÓRIA, 2019). quem moldar a imagem da BRI entre os setores da sociedade brasileira - empresariado, decisionmakers, academia, membros do governo, classe política, sociedade civil e opinião pública. Por outro lado, deve-se ter em mente que o grau de polarização social e ideológica no Brasil torna a construção de consensos especialmente desafiadora.

Essa mudança, entretanto, requer um esforço institucional por parte da China com relação a três dimensões em especial. Em primeiro lugar, maior clareza quanto aos reais objetivos da BRI do ponto de vista das relações bilaterais. Em segundo, maior transparência quanto aos mecanismos de governança e decisão. Em terceiro e, especialmente, deixar mais claro que a BRI não se resume a um pacote de investimentos, mas que consiste em uma ampla iniciativa que pretende estreitar os laços econômicos, sociais e culturais entre as nações.

Vale ressaltar que tal estratégia deve ser deliberadamente direcionada e customizada para os países da América Latina, devido às suas especificidades institucionais e culturais. Nesses países, dentre eles o Brasil, a China ainda é largamente vista como um país distante, não apenas geograficamente, mas também do ponto de vista cultural e dos costumes, como um lugar exótico e cuja aproximação enfrenta obstáculos. Não obstante, é interessante notar a percepção dos brasileiros com relação à China. A avaliação negativa declinou de $28.0 \%$ para $23.5 \%$ entre 2005 e 2018 , ao passo que a avaliação "muito positiva" subiu de $9.4 \%$ para $17.6 \%$, de acordo com dados do Latinobarômetro.

Esses fatores não devem ser subestimados. No plano institucional, mais especificamente, destaca-se o fato de que as estruturas estatais e o setor privado são deficientes para articular estratégias de longo prazo e sinalizar às empresas chinesas as ações necessárias para a coordenação de grandes projetos de cooperação, tal como a BRI (CENTRO BRASILEIRO DE RELAÇÕES INTERNACIONAIS, 2018, p. 11). Justamente por isso, o papel da China também reside no esforço de suprir esta parcial ausência de know-how institucional.

Por outro lado, o Brasil tem um arcabouço regulatório maduro e dispõe de mercado de capitais robusto o suficiente para torná-lo menos dependente de financiamento externo, diferentemente de boa parte dos países que já aderiram à BRI até o momento. Isto configura uma excelente oportunidade para que a China apresente ao resto do mundo a BRI como uma forma de parceria equilibrada, indo de encontro às três principais críticas que a iniciativa tem sofrido: ser um mecanismo de subordinação econômica através do debt-trap; incapacidade na coordenação de arranjos de governança complexos; e impactos socioambientais negativos (CENTRO BRASILEIRO DE RELAÇÕES INTERNACIONAIS, 2019).

Destaca-se, ainda, o fato de que, embora a BRI deva se efetivar primeiramente a partir da adesão em nível nacional, a eventual ausência de uma efetiva coordenação federal não impede os estados brasileiros de propor e executar acordos de cooperação internacional. Isso, de fato, já vem ocorrendo, em grande medida no que tange às relações entre Brasil e China, especialmente nos estados do Nordeste brasileiro (MELLO, 2019). A incorporação à BRI pode potencializar ainda mais este arranjo, ideia que já foi inclusive aventada pelo governador de São Paulo ${ }^{12}$. 
Em princípio pode parecer, a olhos incautos, que a adesão à BRI depende apenas de que o Brasil aceite o convite chinês. É certo que o Brasil ainda precisa definir melhor as suas prioridades e os seus interesses no processo de estreitamento das relações com a China (NEVES, 2019), destacando-se aí o lugar a ser ocupado na BRI. Porém, o sucesso da parceria também depende do esforço da China em mostrar à sociedade brasileira o que tem a oferecer. Feito isso, a BRI tem tudo para se consolidar como um canal promissor de cooperação entre os países.

\section{Referências}

ABDENUR, Adriana; MUGGAH, Robert. A Nova Rota da Seda e o Brasil. Le Monde Diplomatique, 2017. Disponível em: https://diplomatique.org.br/a-nova-rota-da-seda-e-o-brasil/. Acesso em: 15 ago. 2019.

ARAÚJO, Carla; RITTNER, Daniel; MURAKAWA, Fabio. Mourão diz que o Brasil rejeita bloqueio à Huawei. Valor Econômico, 2019. Disponível em: https://valor.globo.com/brasil/noticia/2019/06/07/mourao-diz-que-o-brasil-rejeita-bloqueio-a-huawei.ghtml. Acesso em: 10 nov. 2019.

ARBACHE, J. ¿Y las inversiones en infraestructura?. Banco de Desarrollo de América Latina (CAF), 2019. Disponível em: https://www.caf.com/es/conocimiento/blog/2019/01/y-las-inversiones-en-infraestructura/. Acesso em: 10 nov. 2019.

BELT AND ROAD INITIATIVE. Belt and Road Initiative, 2019. Disponível em: https://www. beltroad-initiative.com/belt-and-road/. Acesso em: 30 jul. 2019.

BELT AND ROAD PORTAL. Belt and Road Portal, 2019. Disponível em: https://eng.yidaiyilu. gov.cn/index.htm. Acesso em: 25 jul. 2019.

CARIELLO, T. Um passo importante para as relações Brasil-China. CEBC ALERTA, informativo, n. 116, 2019. Disponível em: http://www.cebc.com.br/arquivos_cebc/cebc-alerta/Ed\%20 116.pdf. Acesso em: 10 nov. 2019.

CARMINATI, D. China's Belt and Road Initiative: Debt Trap or Soft Power Catalyst?. E-International Relations, 2019. Disponível em: https://www.e-ir.info/2019/09/01/chinas-belt-and-road-initiative-debt-trap-or-soft-power-catalyst/. Acesso em: 10 nov. 2019.

CENTRO BRASILEIRO DE RELAÇÕES INTERNACIONAIS. Brasil-China: o estado da relação, Belt and Road e lições para o futuro. Rio de Janeiro: CEBRI, setembro 2019. Disponível em: http://www.cebri.org/m/portal/publicacoes/cebri-artigos/brasil---china,-o-estado-da-relacao,-belt-and-road-e-licoes-para-o-futuro;jsessionid=493698F3FAEFF5C1D12714B7CC91FAF7. Acesso em: 10 nov. 2019.

CENTRO BRASILEIRO DE RELAÇÕES INTERNACIONAIS. 45 anos Relações Diplomáticas Brasil-China: Do comércio para uma parceria global. Rio de Janeiro: CEBRI, janeiro 2020. Disponível em: http://midias.cebri.org/arquivo/Seminario\%20Brasil\%20China\%20Tendencias\%20e\%20Oportunidades\%20Final.pdf. Acesso em: 2 fev. 2020.

CHARLEAUX, João. Como a $1^{\text {a }}$ base militar da China no exterior mexe com a geopolítica, segundo este professor. Jornal Nexo, 2017. Disponível em: https://www.nexojornal.com.br/ entrevista/2017/08/05/Como-a-1\%C2\%AA-base-militar-da-China-no-exterior-mexe-com-a-geopol\%C3\%ADtica-segundo-este-professor. Acesso em: 20 jul. 2019.

CHINA DAILY. No reason for 'Tropical Trump' to disrupt relations with China. China Daily editorial, 2018. Disponível em: http://www.chinadaily.com.cn/a/201810/29/WS5bd702e9a310eff303285424.html. Acesso em: 20 de julho de 2019.

CONSELHO EMPRESARIAL BRASIL CHINA. Investimentos Chineses no Brasil 2016. Rio de Janeiro: CEBC, 2017. Disponível em: https://cebc.org.br/2018/12/11/investimentos-chineses-no-brasil-2016/. Acesso em: 20 jul. 2019.

CONSELHO EMPRESARIAL BRASIL CHINA. Investimentos Chineses no Brasil 2017. Rio de Janeiro: CEBC, 2018. Disponível em: https://cebc.org.br/2018/12/11/investimentos-chineses-no-brasil-2017/. Acesso em: 20 jul. 2019.

CONSELHO EMPRESARIAL BRASIL CHINA. Uma análise dos investimentos chineses no Brasil: 2007-2012. Rio de Janeiro: CEBC, 2013. Disponível em: https://www.cebc.org.br/sites/default/files/pesquisa_investimentos_chineses_2007-2012_-_digital_1.pdf. Acesso em: 20 jul. 2019. 
COUNCIL ON FOREIGN RELATIONS. Mapping China’s Silk Road, 2019. Disponível em: https://www.cfr.org/blog/mapping-chinas-health-silk-road. Acesso em 25 jul. 2019.

CYSNE, R. Comércio exterior brasileiro: China desloca Estados Unidos e área do euro. Conjuntura Econômica, p. 31-33, abr. 2019. Disponível em: https://epge.fgv.br/pt/noticia/comercio-exterior-brasileiro-china-desloca-estados-unidos-e-area-do-euro-rubens-penha-cysne. Acesso em: 2 nov. 2019.

DÓRIA, J. São Paulo e China, uma história promissora. Folha de São Paulo, 2019. Disponível em: https://opiniao.estadao.com.br/noticias/espaco-aberto,sao-paulo-e-china-uma-historia-promissora,70002961814. Acesso em 2 nov. 2019.

HIRATUKA, C. Mudanças na estratégia chinesa de desenvolvimento no período pós-crise global e impactos sobre a AL. Texto Para Discussão 339, Campinas, Instituto de Economia/Unicamp, n.339, p. 1-20, mai. 2018. Disponível em: http://www.eco.unicamp.br/images/arquivos/ artigos/3630/TD339.pdf. Acesso em: 20 jul. 2019.

KYNGE, James. Megaprojeto chinês eleva dívida de países. Valor Econômico, 2018. Disponível em: https:/valor.globo.com/mundo/coluna/megaprojeto-chines-eleva-divida-de-paises.ghtml. Acesso em 25 jul. 2019.

KUPFER, D.; ROCHA, F. Direções do investimento chinês no Brasil 2010-2016: estratégia nacional ou busca de oportunidades. In: JAGUARIBE, Anna (ed.). Direction of Chinese Global Investments: Implications for Brazil. Brasília: FUNAG, 2018. cap. 6, p. 215-266. Disponível em: https://www.ie.ufrj.br/images/IE/grupos/GIC/publica\%C3\%A7\%C3\%B5es/2018.\%20Kupfer\%20e\%20Freitas,\%20Felipe.\%20CHINESE-GLOBAL-INVESTIMENT_FINAL.pdf. Acesso em: 25 jul. 2019.

LIY, Macarena. China se projeta como baluarte da ordem mundial em "tempos incertos". El País, 2017. Disponível em: https://brasil.elpais.com/brasil/2017/01/27/internacional/1485521277_809514.html. Acesso em 20 jul. 2019.

LIY, Macarena. Em contraponto a Trump, China e Rússia estreitam laços e ampliam acordos. El País, 2018. Disponível em: https://brasil.elpais.com/brasil/2018/06/08/internacional/1528474142_097778.html. Acesso em 25 jul. 2019.

MEDEIROS FILHO, Barnabé. O Golpe no Brasil e a reorganização imperialista em tempo de globalização. Le Monde Diplomatique, 2018. Disponível em: https://diplomatique.org.br/o-golpe-no-brasil-e-a-reorganizacao-imperialista-em-tempo-de-globalizacao/. Acesso em 25 jul. 2019.

MELLO, P. Nordeste vira palco de guerra fria tecnológica. Folha de São Paulo, São Paulo, 30 agosto 2019. Disponível em: https://www1.folha.uol.com.br/mundo/2019/08/nordeste-vira-palco-de-guerra-fria-tecnologica-entre-eua-e-china.shtml. Acesso em: 25 jul. 2019.

MENEZES, V. Desemprego, família e acesso a recursos: contribuições a partir da análise lexical de entrevistas. In: $43^{\circ}$ Encontro da Associação Nacional de Pós-Graduação e Pesquisa em Ciências Sociais. Anais (online), 2019.

MOREIRA, Assis. China tenta atrair Brasil para a Nova Rota da Seda. Valor Econômico, 2019. Disponível em: https://valor.globo.com/brasil/noticia/2019/05/09/china-tenta-atrair-brasil-para-a-nova-rota-da-seda.ghtml. Acesso em 20 nov. 2019.

NEVES, L. A. C. China a longo prazo. Conselho Empresarial Brasil China, Rio de Janeiro, 4 fev. 2019. Disponível em: https://cebc.org.br/2019/02/04/embaixador-castro-neves-china-a-longo-prazo/. Acesso em: 2 nov. 2019.

A evolução dos investimentos públicos: 1947-2017. Observatório de Política Fiscal, 2018. Disponível em: https://observatorio-politica-fiscal.ibre.fgv.br/posts/evolucao-dos-investimentos-publicos-1947-2017. Acesso em 25 jul. 2019.

PIRES, M. C. A iniciativa cinturão e rota: Suas derivações políticas, econômicas e culturais e seus vínculos com o futuro da América Latina. Mundo e Desenvolvimento, v. 1, n. 2, p. 81-102, 2019. Disponível em: http://ieei.unesp.br/index.php/IEEI_MundoeDesenvolvimento/issue/ view/3. Acesso em: 10 nov. 2019 .

PRAZERES, Tatiana. Mundo precisa se adaptar à emergência chinesa como potência. Folha de São Paulo, 2019. Disponível em: https://www1.folha.uol.com.br/mundo/2019/03/mundo-precisa-se-adaptar-a-emergencia-chinesa-como-potencia.shtml. Acesso em 20 jul. 2019.

RATINAUD, P. Amélioration de la précision et de la vitesse de l'algorithme de classification de la méthode Reinert Dans IRaMuTeQ. In: IEZZI, Domenica Fioredistella; CELARDO, Livia; MISURACA, Michelangelo (orgs). JADT' 2018: Proceedings of the 14th international conference on statistical analysis of textual data, Rome: Universitalia, p. 616-625, 2018. 
REN, D. The US-China trade war has been a boon for Brazil's soybean farmers. But can they keep up with Chinese demand?. South China Morning Post, 17 maio 2019. Disponível em: https://www.scmp.com/business/companies/article/3010480/us-china-trade-war-has-been-boon-brazils-soybean-farmers-can. Acesso em: 2 nov. 2019.

SHEN, S.; CHAN, W. A. Comparative study of the Belt and Road Initiative and the Marshall plan. Palgrave Commun, v. 4, n. 32, p. 1-11, 2018. Disponível em: https://doi.org/10.1057/ s41599-018-0077-9. Acesso em: 20 jul. 2019.

SPRING, Jake. Retórica anti-China de Bolsonaro causa apreensão sobre Brasil em Pequim. Reuters, Brasília, 25 novembro 2018. Disponível em: https://br.reuters.com/article/businessNews/ idBRKCN1MZ2SQ-OBRBS. Acesso em: 20 jul. 2019.

VILA NOVA, Carolina. China mira América Latina em seu maior projeto de influência exterior. Folha de São Paulo, 2019. Disponível em: https://www1.folha.uol.com.br/mundo/2019/03/china-mira-america-latina-em-seu-maior-projeto-de-influencia-exterior.shtml. Acesso em 25 jul. 2019.

ZHIWEI, Z. Prospect of China-Brazil relations from the perspective of "The Belt and road Initiative”. Revista Mundo e Desenvolvimento, p.148-172, 2019. Disponível em: https://ieei.unesp. br/index.php/IEEI_MundoeDesenvolvimento/article/download/43/34. Acesso em: 10 nov. 2019. 